\title{
Using copper stable isotopes in the detection of Alzheimer's Disease
}

\author{
FRÉDÉRIC MOYNIER ${ }^{1}$, JOHN CREECH ${ }^{2}$, ESTHER \\ LAHOUD $^{3}$, JESSICA DALLAS ${ }^{3}$, JACQUES HUGON ${ }^{4}$, \\ CLAIRE PAQUET $^{4}$, BRANDON MAHAN $^{5}$ AND MARIE LE \\ BORGNE $^{6}$
}

${ }^{1}$ Université de Paris, Institut de physique du globe de Paris

${ }^{2}$ Macquarie University

${ }^{3}$ Institut de Physique du Globe de Paris

${ }^{4}$ Centre de Neurologie Cognitive, Hopital Lariboisière APHP

Université de Paris, France

${ }^{5}$ James Cook University

${ }^{6}$ Unité 1148 (INSERM), Hôpital Xavier Bichat, Université de

Paris.

Presenting Author: moynier@ipgp.fr

\begin{abstract}
Alzheimer's disease (AD) is a leading cause of death in highincome countries, and afflicts one out of ten people 65 or older worldwide. One of the major physiological features of AD is the formation of senile plaques associated with extracellular deposition of metal-rich (e.g. $\mathrm{Cu}, \mathrm{Zn}$ ) amyloid $\beta(\mathrm{A} \beta$ ) fibrils and the accumulation of tau proteins. The natural stable isotopic composition of metals such as $\mathrm{Zn}, \mathrm{Cu}$ and Fe vary between bodily organs and show very limited natural variations. They are therefore powerful tracers of metal inbalance in the body. In particular, blood is isotopically distinct in $\mathrm{Zn}, \mathrm{Cu}$ and $\mathrm{Fe}$ from the brain. The speciation (bonding) of metals in $A \beta$ fibrils is different to that in the healthy brain, and this can modify the isotopic distribution of metals between the brain and body fluids. Here we will present serum and brain $\mathrm{Cu}$ isotopic compositions of (i) APPswe/PSEN1dE9 transgenic mice (a model of AD), (ii) wild-type (WT) controls for 3, 6, 9 and 12-month-old mice, (iii) human brain tissues including both $\mathrm{AD}$ and healthy patients (Moynier et al. 2020), and (iv) AD-afflicted and healthy human cerebropinal fluids (work in progress). We find that $\mathrm{AD}$-afflicted brains of mice and humans are isotopically lighter for $\mathrm{Cu}$ than brains of healthy mice and patients. We suggest that this reflects an increase of $\mathrm{Cu}(\mathrm{I})$ associated with the formation of $\mathrm{A} \beta$ fibrils and accumulation of tau proteins. In the mice, the $\mathrm{Cu}$ isotopic composition of the brains and serum were correlated, implying copper transport between these two reservoirs, in particular a transfer of $\mathrm{Cu}(\mathrm{I})$ from the brain to the serum. These data suggest that the $\mathrm{Cu}$ stable isotopic composition of body fluid(s) may have the potential to be used as detection tools for the formation of $A \beta$ fibrils in the brain.
\end{abstract}

Moynier et al. A\&D dadm, 2021 doi: 10.1002/dad2.12112 